\title{
Can Energy Democracy Thrive in a Non-democracy?
}

\author{
Laurence L. Delina* \\ Frederick S. Pardee Center for the Study of the Longer-Range Future, Boston University, Boston, MA, United States
}

This paper argues that energy democracy could manifest in terms of public engagement at the community level, free of state intervention, government fostering, and donor support, even in locations where governments have been in flux from a democracy to a non-democracy. In currently non-democratic Thailand, for example, public engagement on community energy transitions had occurred, were sustained, and proved to be durable over time. The spaces of deliberation, created and nurtured by Thai citizens in this community, had become effective sites for navigating and negotiating the ebbs and flows of democratically organized sociotechnical energy transitions. This paper further argues that these spaces for public engagement had revealed that energy democracy is collective, cultural, consequential, co-produced, co-existent, and critical phenomenon

OPEN ACCESS

Edited by:

Leah Sprain,

University of Colorado Boulder,

United States

Reviewed by:

Jennifer Peeples,

Utah State University, United States

Lemir Teron,

SUNY College of Environmental Science and Forestry, United States

*Correspondence:

Laurence L. Delina Idelina@bu.edu

Specialty section:

This article was submitted to

Science and Environmental

Communication,

a section of the journal

Frontiers in Environmental Science

Received: 18 October 2017 Accepted: 16 January 2018 Published: 31 January 2018

Citation:

Delina LL (2018) Can Energy Democracy Thrive in a Non-democracy?

Front. Environ. Sci. 6:5.

doi: 10.3389/fenvs.2018.00005 that can be used to shore up an energy democracy framework.

Keywords: energy democracy, citizen engagement, public participation, energy transitions, community energy, Thailand

"What is the meaning of democracy, freedom, human dignity, standard of living, self-realization, fulfillment? Is it a matter of goods, or of people? Of course it is a matter of people. But people can be themselves only in small comprehensible groups." -Ernst Friedrich (Shumacher, 1973): 75, Small is Beautiful: Economics as if People Mattered.

\section{INTRODUCTION}

Governance at one level impacts governance at other levels. Osmosis and traffic, thus, is the norm in contemporary governing. This notion is manifest in the Paris Agreement on climate change in its call for a multilevel action on decarbonisation of energy systems (United Nations Framework Convention on Climate Change, 2015). By multilevel, it means that energy transitions have to occur across scales-from the global to the national to the subnational or the "local." The focus on the subnational and the local is underlined in the Agreement with the term "subnational" used six times, and "local" seven. So much of the energy transitions will ultimately occur at smaller scale, local and community actions, interventions, and innovations. These "blossoming of a thousand flowers" were indeed instrumental in the German Energiewende (Morris and Jungjohann, 2016), and had attracted following in the UK (Seyfang et al., 2013) among many other spaces and jurisdictions. While much has been written in this area in developed societies, scholars have also been tackling localized energy transitions in developing countries (Delina, 2018), albeit in various guises such as energy access (e.g., Sovacool and Drupady, 2012). There seems to be a veneer, however, blocking our focused gaze on community-based energy transitions as they occur in countries with non-democratic governments. But, can energy democracy thrive in these spaces?

This perspective piece seeks to respond to this question by providing an empirical case study as evidence. I begin with a quick focus on energy democracy as a concept and agenda that is a 
work-in-progress and, at the same time, deeply attached to established contexts of participation and engagement usually and primarily occurring at the community level; hence it is more of a "governance" idea independent of "government." To emphasize this point, I then go on to argue that energy democracy is a dynamic concept, and that its dynamics are constantly re-imagined-even in contexts such as in places where the government is non-democratic. In making this point, I use a case from Thailand, a developing country in southeast Asia currently governed by a military government. As will be demonstrated, this empirical example suggests that a democratic governance arrangement for sustainable energy access and transitions can exist simultaneously even within a non-democratically governed country. To that end, I highlight the key terms central to energy democracy that I observed in rural Thailand in a section expounding energy democracy as a phenomena. I close the paper with a short concluding remarks.

\section{ENERGY DEMOCRACY AND THE FOCUS ON COMMUNITIES}

Conceptualizing and theorizing "energy democracy" remains an unfinished work, but its general agenda can be understood as one pertaining to the instantiations of citizens mobilized in the project of energy transitions in small groups of households and neighbors for social and economic purposes, among multiple contingent aims. Duly attached to "energy democracy," thus, are the cliché terms "civic engagement" and "public participation." As shown in many European contexts, the spaces by which civic engagement and public participation processes are produced have also underscored a key shift in power relations in that "a thousand flowers blossoming" also came to represent socialpolitical-economic struggles against utilities and large-scale energy systems. Energy transitions, therefore, are not ordinary shifts in technologies; they are also strongly glued to the orderings of human societies, economies, and polities (Jasanoff, 2004). The expansion of community-oriented energy systems as manifest in strategic alliances or networks made their evolution similar to what had been observed amongst social movements, which had also strengthened sociopolitical power for regime change via rhizomatic arrangements (Tarrow, 1998; Delina et al., 2014; Delina and Diesendorf, 2016).

The Paris Agreement, now almost universally adopted, shared the same genesis. Some of its orchestrators namely, Laurence Tubiana (Pardee Center, 2016), the French Government's Special Representative to the Paris climate change talks, and Rachel Kyte (2016), then World Bank Group's Special Envoy for Climate Change, almost in chorus, noted invaluable bottomup approaches as key in realizing the Agreement. If the Paris Agreement signals that global normative ambitions, such as addressing climate change, requires hands-on approaches involving actions from all conceivable actors at the bottom, energy democracy-once diffused and scaled up-could also offer a robust opportunity for large-scale energy transitions for rapid decarbonization. Interestingly though, the word "democracy" is nowhere to be found in the text of the Agreement.
A focus on the local-at the communities-has long been advanced in the critical literature. Feminist economic geographers, Gibson-Graham (2008), for instance, have almost fixated their collective work on bringing to light marginalized, hidden and alternative economic activities in many communal practices. Writer and activist, Monbiot (2017), also points to communities for regenerating culture and making politics in contemporary times that are choke-full of mistrust in government and markets relevant again.

Just like other arenas of public engagement and participation, energy democracy is a dynamic concept. In Energiewende, such dynamism is noticeable in community energy as a response to many entangled issues including risk, new ownership structures and socio-economic opportunities, among others (Morris and Jungjohann, 2016). In other locations, such as in the UK, energy democracy reveals community energy as spaces where citizens organized together, among others, to improve social cohesion and develop new job opportunities, not just for seeking environmental ends (Seyfang et al., 2013). What these examples show us, thus far, is that, the concepts and practices of energy democracy are changing in interpretations, with its meanings dynamically interpreted and reinterpreted. What matters at this stage, therefore, is a nod toward reflexivity, i.e., an acceptance of the many inevitable openings and closures that exist as we imagine these new social orders (Stirling, 2015).

With the concept of energy democracy in flux, localized energy transitions are also underscoring emerging opportunities for citizen engagement and participation, including in communities in developing countries. Community-based public engagement in these locations is not a new field of study. Nobel laureate Ostrom (1990) had documented the various structures of these many practices that even pre-date industrialization for common resource management. Another Nobel laureate Sen (2006) also notes similar long tradition of Indian civic engagement. As communities are, once again, called on in the transitions project, understanding their dynamics and learning from their practices have become an imperative for scholarship and practice. One of the many atomized communities where these dynamics could be observed is in non-democratic Thailand.

\section{STUDY SITE AND METHODS}

Thailand emerged as an upper-middle income economy in 2011 from a low-income country in less than a generation (World Bank, 2011). Alongside this economic development are its rising emissions-from $152 \mathrm{MtCO}_{2} \mathrm{e}$ in 1990 to 369 in 2013 (World Resources Institute, 2017). Despite its impressive industrialization, however, Thailand is still home to significant rural poverty, with more than six million poor people living in rural areas (World Bank, 2017). Thailand also has an almost rough contemporary politics stamped by a series of protests and take-overs. Since 2014 up to this writing, Thailand is under a military government, which makes it a non-democratic state. Despite the ebbs and flows by which Thailand is governed, energy democracy seems to thrive in a Thai community $275 \mathrm{~km}$ southwest of the capital, Bangkok. 
This community is located in $\mathrm{Pa}$ Deng town, Kaeng Krachan district, Phetchaburi province. Kaeng Krachan also happens to be the name of Thailand's largest and oldest national park. I have visited this community in November 2016 to January 2017 and conducted qualitative data gathering techniques including observations, face-to-face interviews and small group discussions. All subjects gave oral informed consent in accordance with the recommendations of the Internal Review Board of Boston University, which also stated that this project is not human subjects research (Protocol No 4103X, notification provided on 29 April 2016). Inside this forest, many Thai households raise cattle, pigs and chickens, and plant maize, plums, pineapples, jackfruits and vegetables. About a hundred households had self-organized into communal network following the late King Bhumibol Adulyadej's sethakit por piang (sufficiency economy) idea of development. Sethakit por piang was shaped around cultural forms of communality and Buddhist notions of moderation. [While this development paradigm has been saluted by organizations such as the United Nations Development Programme (United Nations Development Programme, 2007), it is not free of criticism: its open-endedness, for instance, meant that anyone could attach any meaning to it.]

In the Pa Deng network, sethakit por piang is translated in practice around five areas: resiliency, cohesiveness, local economy, livelihoods, and capacity building. At the core of this practice are activities about energy transitions, evidenced by shifts in fuel for cooking, lighting and agriculture services. From charcoal, kerosene and firewood-fuelled cooking, many households had been using biogas trapped in digesters that produced flammable gas from organic matter, primarily cow manure and kitchen leftovers. From diesel-powered system for lighting and irrigation, solar home and irrigation systems had become almost mundane (field notes, November 2016).

\section{ENERGY DEMOCRACY AS A PHENOMENON AND AS A FRAMEWORK}

Key terms central to the idea of energy democracy panned out from these energy practices. At least six of these terms can be identified: collective, cultural, consequential, co-produced, coexistent and critical. These suggest that energy democracy is a phenomena, at the same time that these terms appear to provide the necessary shores for propping up a framework of energy democracy. Using extracts from my field notes, I concisely describe these terms.

The inherent and spontaneous collective response among $\mathrm{Pa}$ Deng citizens sways away from the usual understanding of public engagement as a mere collection of autonomous individuals or an amalgamation of their individual interests. These citizens reveal that this collective act is internal, not external, to any public engagement exercise. A farmer interviewee spoke of this collective spirit: “...I knew that my neighbors, although they live miles away from my home, were also in need for (sustainable energy) technologies...(we like) working together as friends (field notes 11/2016)."

The community's imagined citizen-monarch relationship where the King was afforded a revered status (Fong, 2009) served an important cultural basis for understanding the context of this type of engagement. Ordinary Thai citizens were nudged to participate in the transitions largely since this communal act is deeply moored to the practice of the King's sethakit por piang. These monarch-citizen relations ushered in an almost natural inkling for citizens to participate. Following this, informal engagement simultaneously occurred as farmer-neighbors gather in the evenings over local wine, when gossiping on roadsides, or on their way to town. These culturally embedded spaces had turned into informal sites of energy democracy, where farmers would share their technological innovations.

Another key context for spurring this engagement was the communally identified need for energy access. Since state regulations prohibit grid extension to national parks, the $\mathrm{Pa}$ Deng community could not be connected to the national grid. Finding solutions to address this common need had nudged households to collectively think and act. Communal knowledgeand opportunity-seeking, as it turned out, involved processes of constant experimentation and learning, including copying from what others had been doing. The community's innovative biogas digester system is manifest of these processes.

In 2008, the community decided to test a new technology they saw from their Burmese neighbors: a concrete biogas system. However, they found that they would benefit more if they increase its volume by using cheaper plastic material instead. It turned out that this innovative system could produce more biogas, was easy to operate, maintain and manage, and, in the longer term, was cheaper than buying traditional fuels such as charcoal and kerosene. As a result, this system resulted into monetary savings, which many households could use instead for health and education purposes, as well as for purchasing additional equipment or agricultural farm inputs. Freed up time is another benefit. With time saved from firewood gathering, farmers could now have more time for essential farming work. This consequential character of the Pa Deng communal practice manifested a key aspect of public participation.

Another essential quality of this thriving practice was their inherently produced public participation exercises. Bereft of any state or donor support, the community prospered in their sustainable energy practices by harnessing their own capacities and resources. The community also addressed their challenges by adopting a systems thinking approach, i.e., using a multifaceted understanding of how these challenges could be addressed. Sustainable energy access, thus, was considered not as a simple change of fuel but more about shifts in ways they could live as a community. The transition, thus, is sociotechnical, hence illustrating public engagement as a co-produced interweaving of the social, the normative, and the material (Jasanoff, 2004). Coproduction occurs, not only in terms of farmers highlighting their technical transformations but also by valuing social development, as evident in their sense of communality through camaraderie and cohesion (field notes 11/2016). It is also predicated on the shared interactions between the $\mathrm{Pa}$ Deng public and professionals manifest on co-design and co-delivery of sustainable energy services. An example is when technologists from a nearby university and the Ministry of Energy would visit the community to provide some technical support (field notes 11/2016). 
In Pa Deng, deliberation is pegged as an important exercise for sustaining a sociotechnical innovation. A basic definition of deliberation pertains to a mutual communication involving reflecting over preferences, values and interests on matters of common concern (Dryzek, 2000). Deliberation is used in $\mathrm{Pa}$ Deng in both informal and formal settings, i.e. informally at road interactions or neighborhood gatherings, and formally during their monthly community meetings. These practices illustrate how citizen engagement and public participation could occur in situ and not exclusively within predesigned participatory exercises. In deliberation, citizens would describe their experiences and experimentations toward their energy systems, without fear of being unduly criticized, apprehended, or mocked. Public engagement, thus, is co-existent: as these sites of public engagement thrive, so is energy democracy.

With their sustained deliberation, the Pa Deng community also demonstrates that the virtue of reflexivity is more important in public engagement. Reflexivity refers to the critical practice of assessing one's normative biases and commitments in the practice of collective work. The extent to which reflexivity is practiced in deliberation is in terms of their respect of neighbors who elected not to participate. Indeed, the Pa Deng sociotechnical innovations did not necessarily claim to be genuinely inclusive. In this case, it was impossible to engage all relevant stakeholders in the community. The reasons for non-engagement are multiple but significant to these were-in the case of biogas digesterspeople's perception over the cleanliness of the system and their capacity to purchase expensive fuels such as liquefied petroleum gas tanks. Reflexivity is also manifest with the practice of deliberation. During these exercises, neighbors gathered to give and take arguments on options or issues relevant to them. A farmer provided an example: "I learned that I could substitute (cow manure) with other feedstock such as grass cuttings and some kitchen leftovers. So I thought my (farmer) friend who is not a member of our network will be attracted to join us; but it wasn't enough to convince them... Anyway, our network is voluntary. If you like, then you can join. If you don't, it's still okay. I like that we are not forced to be here. And I like that we are free to talk things out... (field notes 11/2016)."

\section{CONCLUSION}

The materiality of energy transitions is not solely manifest in technological shifts; it is, at best, a marriage between social

\section{REFERENCES}

Delina, L. (2018). Accelerating Sustainable Energy Transition(s) in Developing Countries: The challenge of climate change and sustainable development. Oxon: Routledge.

Delina, L., and Diesendorf, M. (2016). Strengthening the climate action movement: strategies from contemporary social action campaigns. Interface 8, 117-141.

Delina, L., Diesendorf, M., and Merson, J. (2014). Strengthening the climate action movement: strategies from histories. Carbon Management 5, 397-409. doi: 10.1080/17583004.2015.1005396

Dryzek, J. (2000). Deliberative Democracy and Beyond. Oxford: Oxford University Press and technical innovations. The spaces of deliberation, created, nurtured, and sustained by ordinary citizens in Pa Deng had inarguably transformed into effective sites for navigating and negotiating the contradictions, tensions, and contestations of these processes. The sociotechnicality of their engagement also revealed that energy democracy is a collective, cultural, consequential, co-produced, co-existent, and critical governance phenomenon able to manifest and thrive even in places where government systems flow from democracy to non-democracy. This example highlights the relevance of Schumacher who pointed out that people, "in small comprehensible groups," are the matter of democracy. Yet, this community-oriented transition, while it shows an energy democracy in practice, is but a small piece in the larger puzzle of the imperative for a much broader and larger energy transitions. With many communal exercises failing, the $\mathrm{Pa}$ Deng case is specific at best: what happened in $\mathrm{Pa}$ Deng does not necessarily mean "scalable" to other spaces. We, therefore, remain in dire need for more collective efforts to decarbonize energy systems-hence supporting the ideals of the Paris Agreement, and to do it rapidly and democratically. Here, the lessons extracted from the Pa Deng case could best serve us a framework by which we can model energy democracy elsewhere to support these ideals.

\section{AUTHOR CONTRIBUTIONS}

LD designed the study, collected and analyzed the data, and wrote the manuscript.

\section{ACKNOWLEDGMENTS}

This perspective piece is produced as an output of "the future of energy systems in developing countries," a research project at the Frederick S. Pardee Center for the Study of the LongerRange Future at Boston University. It was written during the author's tenure as a Rachel Carson Fellow at LMU Munich. I acknowledge and thank the generous people of $\mathrm{Pa}$ Deng for their time and participation in the study; and Cynthia Barakatt for her comments in the earlier version of the manuscript, Leah Sprain, and two anonymous reviewers for their thoughtful and helpful comments. An earlier version of this paper was presented at the "Energy Democracy: Creating a Research Agenda” symposium at the University of Utah on 12 and 13 July 2017. 
Morris, C., and Jungjohann, A. (2016). Energy Democracy: Germany's Energiewende to Renewables. London: Palgrave Macmillan.

Ostrom, E. (1990). Governing the Commons: The Evolution of Institutions for Collective Action. New York, NY: Cambridge University Press.

Pardee Center (2016). French Ambassador gives inside account of Paris climate deal. Frederick S. Pardee Center for the Study of the Longer-Range Future. Boston University. Available online at: https://www.bu.edu/pardee/2016/02/09/frenchambassador-gives-inside-account-of-paris-climate-deal/

Sen, A. (2006). Argumentative Indian. London: Picador.

Seyfang, G., Park, J. J., and Smith, A. (2013). A thousand flowers blooming? An examination of community energy in the UK. Energy Policy 61, 977-989. doi: 10.1016/j.enpol.2013.06.030

Shumacher, E. F. (1973). Small is Beautiful: Economics as if People Mattered. New York, NY: Harper \& Row.

Sovacool, B. K., and Drupady, I. M. (2012). Energy Access, Poverty, and Development: The Governance of Small-Scale Renewable Energy in Developing Asia. Abongdon: Routledge.

Stirling, A. (2015). "From controlling 'the transition' to culturing plural radical progress," in The Politics of Green Transformations, eds I. Scoones, M. Leach, and P. Newell (London: Routledge), 54-67.

Tarrow, S. (1998). Power in Movement: Social Movements and Contentious Politics. New York, NY: Cambridge University Press.
United Nations Development Programme (2007). (UNDP) Thailand Human Development Report 2007: Sufficiency Economy and Human Development. Bangkok: UNDP.

United Nations Framework Convention on Climate Change (2015). Adoption of the Paris Agreement. UNFCCC. FCCC/CP/2015/L.9

World Bank (2011). Thailand Now an Upper Middle Income Economy. Available online: https:/www.worldbank.org/en/news/press-release/2011/08/ 02/thailand-now-upper-middle-income-economy

World Bank (2017). The World Bank in Thailand. Available online: https://www.worldbank.org/en/country/thailand/overview

World Resources Institute (2017). CAIT Database. Available online: https://cait.wri.org

Conflict of Interest Statement: The author declares that the research was conducted in the absence of any commercial or financial relationships that could be construed as a potential conflict of interest.

Copyright (C) 2018 Delina. This is an open-access article distributed under the terms of the Creative Commons Attribution License (CC BY). The use, distribution or reproduction in other forums is permitted, provided the original author(s) and the copyright owner are credited and that the original publication in this journal is cited, in accordance with accepted academic practice. No use, distribution or reproduction is permitted which does not comply with these terms. 